\title{
Alkaloids as Potential Phytochemicals against SARS-CoV-2: Approaches to the Associated Pivotal Mechanisms
}

\author{
Mohammad Bagher Majnooni ${ }^{1},{ }^{1}$ Sajad Fakhri ${ }^{D},{ }^{2}$ Gholamreza Bahrami ${ }^{2,3}$ \\ Maryam Naseri $\left(\mathbb{D},{ }^{2}\right.$ Mohammad Hosein Farzaei $(\mathbb{D}),{ }^{2}$ and Javier Echeverría $\mathbb{D}^{4}$ \\ ${ }^{1}$ Student Research Committee, Kermanshah University of Medical Sciences, Kermanshah, Iran \\ ${ }^{2}$ Pharmaceutical Sciences Research Center, Health Institute, Kermanshah University of Medical Sciences, Kermanshah, Iran \\ ${ }^{3}$ Medical Biology Research Center, Health Technology Institute, Kermanshah University of Medical Sciences, Kermanshah, Iran \\ ${ }^{4}$ Departamento de Ciencias del Ambiente, Facultad de Química y Biología, Universidad de Santiago de Chile, Santiago, Chile
}

Correspondence should be addressed to Mohammad Hosein Farzaei; mh.farzaei@gmail.com

Received 21 December 2020; Accepted 3 May 2021; Published 20 May 2021

Academic Editor: Shih-Chao Lin

Copyright (c) 2021 Mohammad Bagher Majnooni et al. This is an open access article distributed under the Creative Commons Attribution License, which permits unrestricted use, distribution, and reproduction in any medium, provided the original work is properly cited.

\begin{abstract}
Since its inception, the coronavirus disease 2019 (COVID-19) pandemic has infected millions of people around the world. Therefore, it is necessary to find effective treatments against Severe Acute Respiratory Syndrome Coronavirus-2 (SARS-CoV-2), as it is the viral source of COVID-19. Alkaloids are one of the most widespread plant-derived natural compounds with prominent antiviral effects. Accordingly, these phytochemicals have been promising candidates towards discovering effective treatments for COVID-19. Alkaloids have shown potential anti-SARS-CoV activities via inhibiting pathogenesis-associated targets of the Coronaviridae family that are required for the virus life cycle. In the current study, the chemistry, plant sources, and antiviral effects of alkaloids, as well as their anti-SARS-CoV-2 effect with related mechanisms, are reviewed towards discovering an effective treatment against COVID-19.
\end{abstract}

\section{Introduction}

Since the onset of coronavirus disease 2019 (COVID-19), extensive efforts have been made to find an effective drug/ vaccine against the causative virus Severe Acute Respiratory Syndrome Coronavirus-2 (SARS-CoV-2) [1]. Considering the potential of medicinal plants and related isolated phytochemicals in targeting various diseases, including viral diseases, they could be helpful candidates in the treatment of COVID-19 [2-4]. Several studies are investigating the effectiveness of medicinal plants and their phytochemicals against SARS-CoV [5]. By containing one or more nitrogen atom(s) in their structure, alkaloids are one of the most widespread phytochemicals in plant families such as Amaryllidaceae, Apocynaceae, Papaveraceae, Asteraceae, and Solanaceae possessing potential biological activities and pharmacological effects $[6,7]$. Besides, several studies have shown the prominent effects of alkaloids on various types of viruses such as influenza viruses, herpes simplex virus, human immunodeficiency virus, and hepatitis $C$ virus $[8,9]$. Also, previous in vitro and in silico studies have indicated the prominent effects of alkaloids against coronaviruses, especially SARS-CoV-2. The virus employs different mechanisms such as inhibition of the main protease (Mpro) and RNAdependent RNA polymerase (RdRp), as well as interaction with coronavirus-associated structural proteins $[10,11]$. This study aims to review the antiviral effects of alkaloids, especially against SARS-CoV-2, as well as their mechanisms regarding discovering effective compounds for the treatment of COVID-19.

\section{Chemistry and Natural Sources of Alkaloids}

Alkaloids are a wide group of naturally occurring organic compounds being a major part of the largest group of plant secondary metabolites [12]. The main characteristic feature 
of alkaloids is the presence of nitrogen atom/atoms in a negative oxidation state at their structures [13], which causes their alkaline properties with associated therapeutic effects [12-14]. From the synthesis point of view, most alkaloids are derived from a restricted number of amino acid precursors such as phenylalanine, tyrosine, tryptophan, ornithine, and lysine. These precursors are converted to versatile central intermediates, which results in the production of various alkaloids. When plant species contain more than $0.001 \%$ of alkaloids, they are considered as alkaloids sources. Accordingly, Amaryllidaceae, Apocynaceae, Papaveraceae, Asteraceae, Solanaceae, Rutaceae, Fabaceae, and Rubiaceae are some plant families with the potential of being used for pharmaceutical purposes [15].

Many alkaloids are used in human diet, both in food and drinks, such as alkaloids available in coffee seeds (caffeine), cacao seeds (theobromine and caffeine), tea leaves (theophylline and caffeine), tomatoes (tomatine), and potatoes (solanine) [8]. In addition to their edible uses, alkaloids also play a prominent role in human medical history and are widely used for the treatment of various diseases such as neurological disorders [16], cancer [17], metabolic disorder [18], and infectious diseases [19].

\section{Antiviral Activities of Alkaloids}

Plant-derived alkaloids have been widely considered as potential antiviral sources. In this regard, the effectiveness of alkaloids from Corydalis saxicola Bunting (Papaveraceae) was evaluated against hepatitis B virus. Eight protoberberine-type alkaloids were isolated from the methanolic $(\mathrm{MeOH})$ extracts of this herb. These alkaloids showed inhibitory effects on the activity of HBsAg (hepatitis B surface antigen) and HBeAg (hepatitis B antigen) [20].

O'Rourke and coworkers investigated the inhibitory effects of alkaloids extracted from the sponge Stylissa carteri (Scopalinidae) on Human Immunodeficiency Virus (HIV1). They detected three metabolites termed debromohymenialdisine $(\mathrm{DBH})$, hymenialdisine (HD), and oroidin with anti-HIV-1 activities. Nuclear factor-kappa B (NF- $\kappa$ B), $\mathrm{CDK} 2$, and G2-checkpoint interference were shown as three proposed therapeutic targets towards explaining the inhibitory effects of $\mathrm{HD}$ and $\mathrm{DBH}$. Besides, while oroidin inhibited the retroviral reverse transcriptase, $\mathrm{DBH}$ and HD were ineffective [21]. Lycoris radiata (L'Hér.) of Amaryllidaceae is known for its antiviral potential against influenza virus type A. Four alkaloids, lycorine, hippeastrine, hemanthamine, and 11-hydroxyvittatine, showed antiviral activities against avian influenza virus $\mathrm{H} 5 \mathrm{~N} 1$ after virus entry into cells. Lycorine and hemanthamine also exhibited more potent antiviral activities, due to their inhibitory effects on nuclear-to-cytoplasmic export of the viral ribonucleoprotein complex, which play important roles in viral generation. Thus, Amaryllidaceae alkaloids seem to be potential anti-influenza agents [22].

Traditional Chinese herbal medicine is another source of alkaloids with antiviral activities. Nakamura et al. investigated the antiviral activities of 30 Chinese medicinal plants against herpes simplex virus- (HSV-) 1. They found that
Stephania cepharantha Hayata (Menispermaceae) was the most potent antiviral plant and then isolated 49 alkaloids from its $\mathrm{MeOH}$ extract. Among those extracted ones, seventeen alkaloids were of thirteen bisbenzylisoquinolines, two morphinanes, one proaporphine, and one protoberberine possessing anti-HSV activities [23]. In another study, the effects of novel synthesis derivatives of quinolizidine alkaloid (-)-cytisine were studied against human influenza virus A (H1N1) and parainfluenza virus type 3 (HPIV3). As the result, 9-carboxamides of methylcytisine compounds were the most effective anti-H1N1 agents, which was in line with the result of in silico interactions with the Protein Data Bank code 4R7B active site of influenza A virus neuraminidase. Furthermore, derivatives with allyl isocyanate and (-)-cytisine or 9,11-dibromocytisin exerted inhibitory effects in HPIV3 reproduction [24].

The methanolic extract of the root bark of Schumanniophyton magnificum (K.Schum.) Harms (Rubiaceae) was tested to evaluate its antiviral activities against HIV and HSV, resulted in finding schumannificine 1 and other chromone alkaloids and acyl and methyl derivatives. Among those alkaloids, schumannificine 1 exhibited the highest anti-HIV activity due to its structural existence of piperidine ring and unsubstituted hydroxy groups, while a number of its derivatives exhibited anti-HSV activities [25]. In another study, two new and six known carbazole alkaloids from Clausena anisum-olens (Blanco) Merr. (Rutaceae) were evaluated on the HIV. They reported the highest antiviral activity against HIV virus for one of the new carbazole alkaloids [26]. Four pairs of enantiomers named ( \pm )- $\beta$-myrifabral $\mathrm{A},( \pm)$ - $\alpha$-myrifabral $\mathrm{A},( \pm)$ - $\beta$-myrifabral $\mathrm{B}$, and $( \pm)-\alpha$-myrifabral B were derived from Myrioneuron faberi Hemsl. ex F.B.Forbes \& Hemsl. (Rubiaceae) as a Chinese herbal plant. These cyclohexane-fused octahydroquinolizine alkaloids exhibited inhibitory effects on hepatitis C virus [27].

Renard-Nozaki et al. investigated the effects of some alkaloids in Amaryllidaceae, which were biosynthesized from $N$-benzylphenethylamine and their derivatives to be assessed against HSV-1 activity, as well as their antiviral mechanisms. The results showed that the synthesized apogalanthamine group possessed an anti-HSV-1 activity due to the related hexahydroindole ring with two functional hydroxyl groups. This hexahydroindole ring was responsible for antiviral activities and inhibition of HSV multiplication instead of extracellular viruses by reduction of viral DNA polymerase activity. In their study, lycorine and its derivative hippeastrine showed the highest antiviral activities among isolated alkaloids [28].

Amongst other traditional Chinese herbs, Tetradium ruticarpum (A. Juss.) T.G.Hartley (syn. Evodia ruteacarpa) (Rutaceae) was used to isolate three major quinazoline alkaloids named dehydroevodiamine, evodiamine, and rutaecarpine. The antiviral activities of these alkaloids were evaluated with showing inhibitory effects on H1N1-induced Regulated upon Activation, Normal T cell Expressed and Secreted (RANTES) production. Evodiamine exhibited the highest anti-H1N1 activity and inhibitory effect against H1N1 virus. This effect was also represented with 
rutaecarpine but not dehydroevodiamine. The results suggested the aforementioned alkaloids as potentially active compounds for the inhibition of H1N1-induced chemokine production as well as the suppression of chemotactic migration and chemokine-attracted leukocyte recruitment [29]. As another traditional Chinese herbal medicine with antiviral activities, Tripterygium hypoglaucum (H.Lév.) Hutch. (Celastraceae) showed promising antiviral effects. In a report by Ren et al., the anti-HSV-1 activity of rootextracted alkaloids was evaluated. These alkaloids decreased related UL30 and UL39 sequences and delayed early genes and US6 viral late gene transcription of HSV-1 genome, which led to the inhibition of HSV-1 activity [30].

Moradi et al. investigated the anti-influenza effects of extracted alkaloids from seeds of Peganum harmala L. (Nitrariaceae). The isolated alkaloids suppressed viral RNA replication and polymerase activity while not suppressing hemagglutination. Thus, the alkaloids of $P$. harmala were suggested as a potential agent against influenza A virus [31]. In a parallel study on the Chinese herbal plant Sophora alopecuroides L. (Fabaceae), the antiviral activity of five new quinolizidine-based alkaloids isolated from the seeds against the hepatitis B virus (HBV) was evaluated. These alkaloids were sparteineindolizine, matrine-indolizine, and epimeric normatrine-julolidine (with unusual skeletons). Anti-HBV activity of matrine-indolizine suggested them as potential antiviral agents [32]. Sun et al. isolated five indole alkaloids from Isatis tinctoria L. (syn. Isatis indigotica) (Brassicaceae), a traditional Chinese herb. All alkaloids exhibited anti-HSV2 activities, with the structures of 3-hydroxy-3-acetonitrile4-hydroxy-2-indolone, 1-methoxy-3-indoleacetonitrile, 3indoleacetic acid, 3-indolealdehyde, and 1-methoxy-3indolecarbaldehyde [33]. Besides, an indolizidine alkaloid from $L$. radiata, lycorine, at $15 \mathrm{nM}$ concentration showed in vitro anti-SARS-CoV activities [34]. The lycorine along with other alkaloids, including tetrandrine, harmine, conessine, and emetine, showed antiviral activities against $\mathrm{HCoV}$ such as $\mathrm{HCoV}-\mathrm{OC} 43$ and $\mathrm{HCoV}-\mathrm{NL63}$. In their study, lycorine was shown to inhibit the propagation and replication of $\mathrm{HCoV}-\mathrm{OC} 43$ in the rat brain, probably through blocking viral proteases [35].

In another research, total alkaloids extracted from Alstonia scholaris (L.) R.Br. (Apocynaceae), another folk herbal plant that is used in China, exhibited anti-influenza effects. These alkaloids suppressed viral replication, increased the survival rate, and exhibited cytokine inhibitory effects at the mRNA/protein levels. They also deactivated the pattern recognition receptor and interferon-activated signal transduction pathway. Total alkaloids also ameliorated innate immune cell infiltration and improved lung histopathology, in vivo [36].

\section{Alkaloids as Potential Phytochemicals against SARS-CoV-2}

Recent studies showed that alkaloids interact with the coronavirus structural proteins, including spike (S) glycoprotein and nucleocapsid $(\mathrm{N})$ on the virus surface, as well as nonstructural angiotensin-converting enzyme 2 (ACE2) in the cell membrane, and, in turn, inhibit the enzymes involved in coronavirus replication, such as RdRp and 3chymotrypsin-like protease (3CL ${ }^{\text {pro }}$ ) [37-39] (Figure 1). Wink suggested that highly DNA-interacting alkaloids, such as sanguinarine, chelerythrine, palmatine, chelidonine, berbamine, berberrubine, coptisine, dicentrine, jatrorrhizine, and berberine, could be suitable agents against SARS-CoV-2 [37]. Besides, a docking study on Tinospora cordifolia (Willd.) Hook.f. \& Thomson (Menispermaceae) alkaloids, berberine $(-7.3 \mathrm{Kcal} / \mathrm{mol})$, and tetrahydropalmatine $(-6.4 \mathrm{kcal} / \mathrm{mol})$ showed a high binding affinity to $3 \mathrm{CL}^{\text {pro }}$ of SARS-CoV-2 [10]. Another docking study reported tryptanthrine $(-8.2 \mathrm{kcal} / \mathrm{mol})$, indirubin $(-7.6 \mathrm{kcal} /$ $\mathrm{mol})$, indigo $(-7.5 \mathrm{kcal} / \mathrm{mol})$, and indican $(-7.5 \mathrm{kcal} / \mathrm{mol})$ as other alkaloids interacting with SARS-CoV-2 Mpro [40]. Besides, tryptanthrine and 5aR-ethyltryptanthrin isolated from methanolic extraction of Strobilanthes cusia (Acanthaceae) revealed anti-human coronavirus ( $\mathrm{HCoV})$ activities in a cytopathic effect reduction assay at $1.52 \mu \mathrm{M}$ and $2.60 \mu \mathrm{M}$, respectively. In addition, tryptanthrine inhibited the HCoV-NL63 infectivity in human lung epithelial cells at $0.30 \mu \mathrm{M}$ with low cytotoxic effects on lung epithelial cells $(\mathrm{CC} 50=173.2 \mu \mathrm{M})$ [41]. On the other hand, due to the prominent antiviral and anti-inflammatory effects of indirubin and indigo, as two indole alkaloids, they can be considered as appropriate candidates for further COVID-19 treatment studies [42-44].

Also, Mpro was the main target for anti-SARS-CoV-2 effects of thalimonine, a pavine alkaloid, and sophaline $\mathrm{D}$, a matrine-acetophenone alkaloid. According to the antitussive activities of thalimonine and antirhinovirus activities of sophaline $\mathrm{D}$, these alkaloids are promising candidates for COVID-19 treatment [45].

In addition to the aforementioned alkaloids, three bisbenzylisoquinoline alkaloids of Stephania tetrandra S. Moore (Menispermaceae), including tetrandrine, cepharanthine, and fangchinoline, inhibited HCoV-OC43 24 hours after treatment at $5 \mu \mathrm{M}$ via reducing the expression of $\mathrm{S}$ and N proteins. The selectivity indices (CC50/IC50) of the tetrandrine, fangchinoline, and cepharanthine on MRC-5 human lung cells were $40.11,11.46$, and $13.63 \mu \mathrm{M}$, respectively, which revealed their low levels of toxicity [46]. In addition to the aforementioned mechanism, cepharanthine showed anti-SARS-CoV-2 effects through the inhibition of $\mathrm{RdRp}$, in silico [47]. Besides, cepharanthine improved the lung injuries, as a critical complication of COVID-19, with the effects on inflammatory signaling pathways. So, cepharanthine could be of promising candidates in combating COVID-19 [48]. Also, Maurya et al. showed that the S glycoprotein of SARS-CoV-2 and ACE2 are major targets of thebaine, berberine, and piperine. Despite the lower oral bioavailability of thebaine, its highest safety has been shown in comparison to other two alkaloids [39].

A docking study on the evaluation of interactions between alkaloids of African plants and $3 \mathrm{CL}^{\text {pro }}$ of coronaviruses showed that 10-hydroxyusambarensine, cryptoquindoline, cryptospirolepine, and chrysopentamine possessed stronger binding affinities than ritonavir and lopinavir [49]. Another study reported that Cryptolepis 


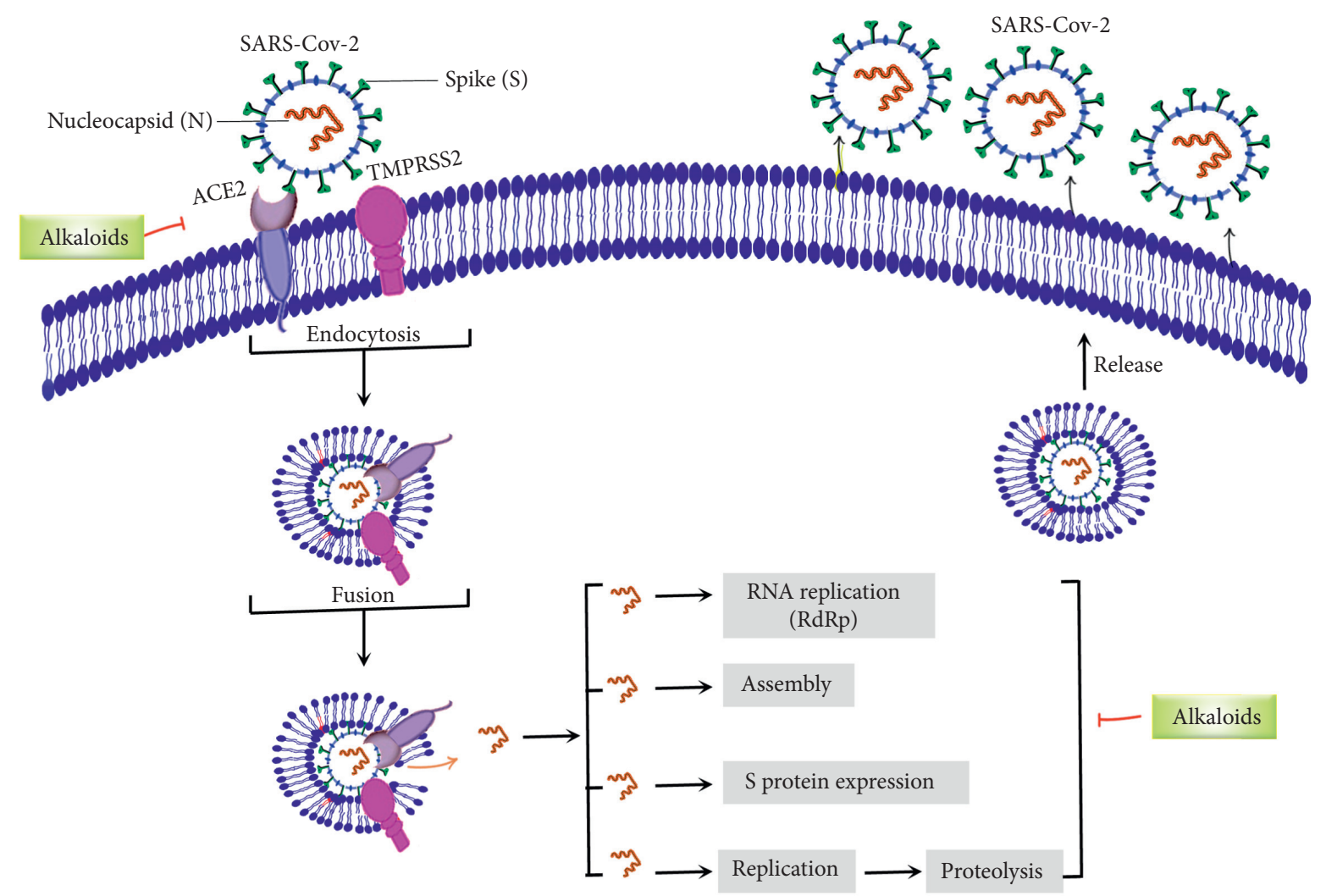

FIGURE 1: Major targets of alkaloids in combating SARS-CoV-2. ACE2: angiotensin-converting enzyme 2, TMPRSS2: transmembrane serine protease 2, and SARS-CoV-2: severe acute respiratory syndrome coronavirus-2.

sanguinolenta alkaloids, including cryptomisrine, cryptospirolepine, and cryptoquindoline, showed acceptable interactions ( $>-8.5 \mathrm{kcal} / \mathrm{Mol}$ ) with $\mathrm{Mpro} / \mathrm{RdRp}$ of SARS-CoV2. In their study, absorption, distribution, metabolism, and excretion (ADMET) property prediction showed that all C. sanguinolenta alkaloids have shown adequate gastrointestinal absorption and are able to cross the blood-brain barrier while possessing a low level of toxicity [50]. In addition, Zhang et al. showed two alkaloids, oxysophoridine, and lycorine with anti-SARS-CoV-2 effects in Vero-E6 cell culture at 0.31 and $0.18 \mu \mathrm{M}$, respectively. In their study, inhibition of nucleotide biosynthesis was suggested for the aforementioned antiviral effects [51]. In addition to its antiSARS-CoV-2 effects, lycorine also has prominent neuroprotective effects that can play a multifaceted role in the treatment of this disease due to the neurological complications of COVID-19 disease [52, 53]. Consequently, Bleasel and Peterson published a commentary on the potential of emetine and ipecac alkaloids as anti-SARS-CoV-2 agents [54]. Recently, the anti-HSV alkaloids, including emetine and homoharringtonine, have been introduced as potential agents in combating COVID-19. Their report was in line with that of Choy et al. in showing in vitro anti-SARS-CoV-2 activities of emetine and homoharringtonine, at 2.55 and $0.46 \mu \mathrm{M}$, respectively $[11,55]$. Additionally, Kumar et al. showed that emetine $(2.3 \mathrm{ng} / \mathrm{egg})$ inhibited SARS-CoV-2 replication via suppressing viral proteins such as viral polymerase in the infecting chicken embryonic model with IBV (chicken coronavirus) [56]. Also, another study showed that homoharringtonine strongly interacted with SARS-CoV-2 S protein among eleven anti-SARS-CoV alkaloids with a LibDock score of $109.11 \mathrm{kcal} / \mathrm{mol}$ [57].

Solanidine is a toxic steroid alkaloid of potato (Solanaceae) possessing a strong binding to SARS-CoV-2 Mpro and $S$ proteins with a binding affinity of -7.0 and $-9.1 \mathrm{kcal} /$ mol, respectively [58]. The binding affinity of anisotine as a quinazoline alkaloid of the leaves of Justicia adhatoda L. (Acanthaceae) to SARS-CoV-2 Mpro was reported to be $-7.9 \mathrm{kcal} / \mathrm{mol}$ that was stronger than that of darunavir and lopinavir, as positive control drugs [59]. Besides, Kar et al. showed the predicted the inhibitory constant (Ki) of anisotine interaction with Mpro, S proteins, and RdRp of SARS$\mathrm{CoV}-2$ was $1.90 \mu \mathrm{M}, 0.70 \mu \mathrm{M}$, and $47.08 \mu \mathrm{M}$, respectively [60].

In two in silico reports, Gurung et al. showed suitable binding affinity of the alkaloids such as 18-hydroxy-3-epialphayohimbine, alloyohimbine, asparagamine A, vincapusine, sophoridine, and lycorine to Mpro of coronaviruses, especially the SARS-CoV-2 [61, 62]. In another study, Gul et al. showed that the alkaloids such as dihydroergotamine and ergotamine possess acceptable inhibitory interactions with SARS-CoV-2 3CL ${ }^{\text {pro }}$ and RdRp [63]. Due to the antiinflammatory effects, especially the neurological inflammation of ergotamine and dihydroergotamine, and the antiviral effects mentioned for them, these two ergot alkaloids could be introduced as promising candidates for the 
treatment of COVID-19 [64]. Also, Mustafa et al. showed that ergometrine and papaverine had the highest docking score in interaction with SARS-CoV-2 Mpro among alkaloids which has been approved to be safe by the FDA for use in various diseases [65].

In addition to their benefits to being used against COVID-19, the absorption, distribution, metabolism, excretion, and toxicity (ADMET) of alkaloids are limiting factors in their usage as anti-SARS-CoV-2 agents. Sanguinarine as a benzophenanthridine alkaloid, palmatine as an isoquinoline alkaloid, and tabersonine as a monoterpenoid indole alkaloid showed a good binding affinity to $3 \mathrm{CL}^{\text {pro }}$ and suitable ADMET properties. However, sanguinarine showed AMES toxicity [66]. Besides, sanguinarine, palmatine, and tabersonine have shown prominent inhibitory effects on inflammatory signaling pathways such as cyclooxygenase-2, mitogen-activated protein kinases, and NF- $\kappa \mathrm{B}$, which have been shown to play a critical role in the development of SARS-CoV-2 complications. So, they could be introduced for further clinical trial studies on COVID-19 patients [67-69].

Besides, in another study, Joshi et al. showed that the (-)-asperlicin $\mathrm{C}$ had high binding affinity to $3 \mathrm{CL}^{\mathrm{pro}}(-9.7 \mathrm{kcal} /$ $\mathrm{mol})$ and ACE2 $(-9.5 \mathrm{kcal} / \mathrm{mol})$, as well as oriciacridone $\mathrm{F}$, with a high binding affinity to $\operatorname{RdRp}(-9.6 \mathrm{kcal} / \mathrm{mol})$ [70]. In addition, tylophorine $(0.018 \mu \mathrm{M})$ as a phenanthroindolizidine alkaloid and 7-methoxycryptopleurine $(<0.005 \mu \mathrm{M})$ as a phenanthroquinolizidine alkaloid showed anti-SARS-CoV activities in Vero 76 cells via the inhibition of $S$ and $N$ proteins and $3 \mathrm{CL}^{\text {pro }}$ [71]. Transmembrane Protease Serine 2 (TMPRSS2) and cathepsin L are two host cell proteases that are required for binding the $\mathrm{S}$ protein of SARS-CoV-2 to host cells and entry. Vivek-Ananth et al. showed the alkaloids such as adlumidine and qingdainone with TMPRSS2 as well as oxoturkiyenine and $3 \alpha, 17 \alpha$-cinchophylline and cathepsin L possess strong interaction and, thereby, are suitable agents against SARS-CoV-2 infection [72].

Envelope (E) protein is another structural protein of SARS-CoV-2 that plays critical roles in the assembly step of virus replication. Berbamine and its derivative (BE33) showed anti-SARS-CoV-2 activity through the inhibition of E protein at 14.50 and $0.94 \mu \mathrm{M}$, respectively. These compounds decreased the lung injury induced by SARS-CoV-2E protein via reducing proinflammatory cytokines in the serum of C57BL/6 mice [73]. In addition to those structural proteins, nonstructural proteins (Nsps), especially Nsp15, have also played critical roles for SARS-CoV-2 replication. Some alkaloids such as ajmalicine $(-8.1 \mathrm{kcal} / \mathrm{mol})$, reserpine $(-7.4 \mathrm{kcal} / \mathrm{mol})$, berberine $(-7.3 \mathrm{kcal} / \mathrm{mol})$, and taspine $(-7.3 \mathrm{kcal} / \mathrm{mol})$ showed anti-SARS-CoV-2 activities via the inhibition of Nsp15 [74]. Berberine could be one of the promising candidates for the treatment of COVID-19 and reducing the side effects induced by SARS-CoV-2. In addition to its prominent antiviral effects on a variety of viruses, this isoquinoline alkaloid exhibited beneficial activities such as antioxidant, anti-inflammatory, immunomodulatory, neuroprotective, cardioprotective, nephroprotective, hepatoprotective, and anti-lung-injury effects $[48,75,76]$.
Noscapine is a phthalideisoquinoline alkaloid from some species of the Papaveraceae family such as Papaver somniferum with antitussive and nonnarcotic effects. Several studies showed the noscapine and its derivatives, especially N-bromobenzyl derivative (23b), have strong and stable interaction with the Mpro enzyme of SARS-CoV-2 and, thereby, they are promising candidates for COVID-19 treatment [77, 78]. Fungi, especially genus Aspergillus, are one of the richest sources of alkaloids. Youssef et al. introduced fumigatoside $\mathrm{E}$ as a promising candidate for the treatment of COVID-19 because this pyrazinoquinazoline indole alkaloid, isolated from Aspergillus fumigatus, had a very strong interaction with ACE2 $(-21.17 \mathrm{kcal} / \mathrm{Mol})$. It also strongly interacted with microbial proteins such as DNAgyrase, topoisomerase IV, and beta-lactamase [79]. Besides, norquinadoline $\mathrm{A}$, as a fungal quinazoline alkaloid isolated from Cladosporium sp, showed strong interaction with ACE2 and papain-like protease (PLpro) with binding energies of $-10.63 \mathrm{kcal} / \mathrm{mol}$ and $-10.90 \mathrm{kcal} / \mathrm{mol}$, respectively. This alkaloid had high safety and appropriate pharmacokinetic behavior in the predictive of ADMET properties $[80,81]$.

Marine natural products including polycyclic guanidine alkaloids, isolated from several species of marine sponges, show prominent biological and pharmacological effects. ElDemerdash et al. reported that crambescidin 786 and crambescidin 826 as two polycyclic guanidine alkaloids strongly interacted with SARS-CoV-2 proteins including Mpro, $\mathrm{S}$ proteins, $\mathrm{N}$ proteins, membrane glycoprotein, and Nsp 10 during a docking study. The highest binding energies of crambescidin 786 and crambescidin 826 were with Nsp 10 $(-9.06 \mathrm{kcal} / \mathrm{mol})$ and $\mathrm{N}$ protein $(-8.01 \mathrm{kcal} / \mathrm{mol})$, respectively. The results of these studies also showed that the presence of long-chain omega fatty acids in the structure of these alkaloids is critical for their strong interactions with SARS-CoV-2 proteins [82].

Caffeine, nicotine [83], and pseudojervine [84] via the interaction with ACE2 and amaranthin [85], speciophylline, cadambine [86], schizanthine $Z$, and schizanthine $Y$ [87] via the interaction with Mpro showed anti-SARS-CoV-2 activities. In addition to the aforementioned agents involved in the pathogenesis of SARS-CoV-2, calcium ions also have shown vital roles for the entry of SARS-CoV-2 to the host cells. Berbamine also blocked the calcium transition, thereby showing anti-SARS-CoV-2 effects [88]. Also, inhibiting the calcium transition was one of the anti-SARS-CoV-2 mechanisms of four bisbenzylisoquinoline alkaloids including cepharanthine, hernandezine, neferine, and tetrandrine, which were selected from among 188 natural compounds studied for anti-SARS-CoV-2 activities. Besides, neferine at $10 \mu \mathrm{M}$ reduced the levels of relative viral RNA by $76.98 \%[89]$.

In a docking study, the alkaloids of Argemone mexicana L. (Papaveraceae) including protopine, allocryptopine, and 6-acetonyldihydrochelerythrine showed a promising interaction with RdRp [38]. Also, in another study on Pilocarpus microphyllus alkaloids (Rutaceae), epiisopiloturine showed a suitable interaction with Mpro $(-7.0 \mathrm{kcal} / \mathrm{mol})$. Nevertheless, this imidazolic alkaloid was detected as a mutagenic 
TABLE 1: In vitro studies of alkaloids with potential anti-SARS-CoV-2 activity.

\begin{tabular}{|c|c|c|c|c|c|}
\hline Alkaloid & Chemical structure & $\begin{array}{l}\text { Mechanisms of } \\
\text { action }\end{array}$ & $\begin{array}{l}\text { Type } \\
\text { of } \\
\text { study }\end{array}$ & EC50 & Ref. \\
\hline $\begin{array}{l}\text { 7- } \\
\text { Methoxycryptopleurine }\end{array}$ & & $\begin{array}{l}\text { Blocking the } S \text { and } \\
\mathrm{N} \text { proteins, } 3 \mathrm{CL}^{\text {pro }} \\
\text { inhibitor }\end{array}$ & $\begin{array}{c}\text { In } \\
\text { vitro }\end{array}$ & $58 \mathrm{nM}$ & {$[71]$} \\
\hline Berbamine & & $\begin{array}{l}\text { Blocking the } \mathrm{E} \\
\text { proteins and the } \\
\text { calcium transition }\end{array}$ & $\begin{array}{l}\text { In } \\
\text { vitro }\end{array}$ & $\begin{array}{l}14.5 \mu \mathrm{M} \\
2.3 \mathrm{mM}\end{array}$ & {$[73,88]$} \\
\hline $\begin{array}{l}\text { Berbamine derivative } \\
\text { (BE33) }\end{array}$ & & $\begin{array}{l}\text { Blocking the } \mathrm{E} \\
\text { proteins }\end{array}$ & $\begin{array}{c}\text { In } \\
\text { vitro }\end{array}$ & $0.94 \mu \mathrm{M}$ & {$[73]$} \\
\hline Cepharanthine & & $\begin{array}{l}\text { Blocking the } \\
\text { expression of } S \text { and } \\
\mathrm{N} \text { proteins, RdRp } \\
\text { inhibitor }\end{array}$ & $\begin{array}{c}\text { In } \\
\text { vitro }\end{array}$ & $0.83 \mu \mathrm{M}$ & {$[46,47]$} \\
\hline Conessine & & Mpro inhibitor & $\begin{array}{l}\text { In } \\
\text { vitro }\end{array}$ & $\begin{array}{l}2.34 \mu \mathrm{M} \\
10.75 \mu \mathrm{M}\end{array}$ & {$[35]$} \\
\hline
\end{tabular}


TABle 1: Continued.

\begin{tabular}{|c|c|c|c|c|c|}
\hline Alkaloid & Chemical structure & $\begin{array}{c}\text { Mechanisms of } \\
\text { action }\end{array}$ & $\begin{array}{l}\text { Type } \\
\text { of } \\
\text { study }\end{array}$ & EC50 & Ref. \\
\hline Emetine & & Mpro inhibitor & $\begin{array}{c}\text { In } \\
\text { vitro }\end{array}$ & $2.55 \mu \mathrm{M}$ & {$[11,55]$} \\
\hline Fangchinoline & & $\begin{array}{l}\text { Blocking the } \\
\text { expression of } S \text { and } \\
\mathrm{N} \text { proteins }\end{array}$ & $\begin{array}{c}\text { In } \\
\text { vitro }\end{array}$ & $1.01 \mu \mathrm{M}$ & {$[46]$} \\
\hline Harmine & & Mpro inhibitor & $\begin{array}{c}\text { In } \\
\text { vitro }\end{array}$ & $\begin{array}{c}1.9 \mu \mathrm{M} \\
13.46 \mu \mathrm{M}\end{array}$ & {$[35]$} \\
\hline Hernandezine & & $\begin{array}{l}\text { Blocking the } \\
\text { calcium transition }\end{array}$ & $\begin{array}{c}\text { In } \\
\text { vitro }\end{array}$ & $10 \mu \mathrm{M}$ & [89] \\
\hline Homoharringtonine & & $\begin{array}{l}\text { Blocking S } \\
\text { proteins }\end{array}$ & $\begin{array}{c}\text { In } \\
\text { vitro }\end{array}$ & $0.46 \mu \mathrm{M}$ & {$[11,55,57]$} \\
\hline Lycorine & & Mpro inhibitor & $\begin{array}{l}\text { In } \\
\text { vitro }\end{array}$ & $\begin{array}{c}15 \mathrm{nM}, \\
0.15 \mu \mathrm{M} \\
0.47 \mu \mathrm{M}\end{array}$ & {$[34,35]$} \\
\hline
\end{tabular}


TABLE 1: Continued.

\begin{tabular}{|c|c|c|c|c|c|}
\hline Alkaloid & Chemical structure & $\begin{array}{l}\text { Mechanisms of } \\
\text { action }\end{array}$ & $\begin{array}{l}\text { Type } \\
\text { of } \\
\text { study }\end{array}$ & EC50 & Ref. \\
\hline Neferine & & $\begin{array}{l}\text { Decreasing the } \\
\text { levels of relative } \\
\text { viral RNA }\end{array}$ & $\begin{array}{c}\text { In } \\
\text { vitro }\end{array}$ & $10 \mu \mathrm{M}$ & [89] \\
\hline Oxysophoridine & & $\begin{array}{l}\text { Nucleotide } \\
\text { biosynthesis } \\
\text { inhibitor }\end{array}$ & $\begin{array}{l}\text { In } \\
\text { vitro }\end{array}$ & $0.31 \mu \mathrm{M}$ & {$[51]$} \\
\hline Quinine & & $\begin{array}{l}\text { Mpro and S } \\
\text { proteins inhibitor } \\
\text { (in silico study) }\end{array}$ & $\begin{array}{l}\text { In } \\
\text { vitro }\end{array}$ & $10.7 \mu \mathrm{M}$ & {$[91,93]$} \\
\hline Tetrandrine & & $\begin{array}{l}\text { Blocking the } \\
\text { expression of } S \text { and } \\
\mathrm{N} \text { proteins, Mpro } \\
\text { inhibitor }\end{array}$ & $\begin{array}{l}\text { In } \\
\text { vitro }\end{array}$ & $\begin{array}{l}0.33 \mu \mathrm{M} \\
0.29 \mu \mathrm{M} \\
2.05 \mu \mathrm{M}\end{array}$ & {$[35,46]$} \\
\hline Tylophorine & & $\begin{array}{c}\text { Blocking the } S \text { and } \\
\mathrm{N} \text { proteins, } 3 \mathrm{CL}^{\text {pro }} \\
\text { inhibitor }\end{array}$ & $\begin{array}{l}\text { In } \\
\text { vitro }\end{array}$ & $20 \mathrm{nM}$ & [53] \\
\hline
\end{tabular}

$3 \mathrm{CL}^{\text {pro }}$ : 3-chymotrypsin-like protease, ACE2: angiotensin-converting enzyme 2, E proteins: envelope proteins, Mpro: main proteases, NI: not identified, $\mathrm{N}$ proteins: nucleocapsid proteins, Nsp15: nonstructural proteins, RdRp: RNA-dependent RNA polymerase, S proteins: spike proteins, TMPRSS2: transmembrane protease serine 2 . 
TABLE 2: In silico studies of alkaloids with potential anti-SARS-CoV-2 activity.

\begin{tabular}{|c|c|c|c|c|}
\hline Alkaloid & Chemical structure & $\begin{array}{c}\text { Mechanisms } \\
\text { of action }\end{array}$ & $\begin{array}{l}\text { Type of } \\
\text { study }\end{array}$ & References \\
\hline (-)-asperlicin $\mathrm{C}$ & & $\begin{array}{c}3 \mathrm{CL}^{\text {pro }} \\
\text { inhibitory, } \\
\text { blocking } \\
\text { ACE2 }\end{array}$ & $\begin{array}{l}\text { Molecular } \\
\text { docking }\end{array}$ & {$[70]$} \\
\hline $3 \alpha, 17 \alpha$-Cinchophylline & & $\begin{array}{l}\text { Cathepsin L } \\
\text { inhibitor }\end{array}$ & $\begin{array}{l}\text { Molecular } \\
\text { docking }\end{array}$ & {$[72]$} \\
\hline 10-Hydroxyusambarensine & & $\begin{array}{l}3 \mathrm{CL}^{\text {pro }} \\
\text { inhibitor }\end{array}$ & $\begin{array}{l}\text { Molecular } \\
\text { docking }\end{array}$ & [49] \\
\hline $\begin{array}{l}\text { 18-Hydroxy-3-epi- } \\
\text { alphayohimbine }\end{array}$ & & $\begin{array}{l}3 \mathrm{CL}^{\text {pro }} \\
\text { inhibitor }\end{array}$ & $\begin{array}{l}\text { Molecular } \\
\text { docking }\end{array}$ & {$[61]$} \\
\hline $\begin{array}{l}\text { 6- } \\
\text { Acetonyldihydrochelerythrine }\end{array}$ & & $\begin{array}{l}\text { RdRp } \\
\text { inhibitor }\end{array}$ & $\begin{array}{l}\text { Molecular } \\
\text { docking }\end{array}$ & {$[38]$} \\
\hline Adlumidine & & $\begin{array}{l}\text { TMPRSS2 } \\
\text { inhibitors }\end{array}$ & $\begin{array}{l}\text { Molecular } \\
\text { docking }\end{array}$ & {$[72]$} \\
\hline
\end{tabular}


TABle 2: Continued.

\begin{tabular}{|c|c|c|c|c|}
\hline Alkaloid & Chemical structure & $\begin{array}{c}\text { Mechanisms } \\
\text { of action }\end{array}$ & $\begin{array}{l}\text { Type of } \\
\text { study }\end{array}$ & References \\
\hline Ajmalicine & & $\begin{array}{l}\text { Blocking } \\
\text { Nsp15 }\end{array}$ & $\begin{array}{l}\text { Molecular } \\
\text { docking }\end{array}$ & {$[74]$} \\
\hline Allocryptopine & & $\begin{array}{c}\text { RdRp } \\
\text { inhibitor }\end{array}$ & $\begin{array}{c}\text { Molecular } \\
\text { docking }\end{array}$ & {$[38]$} \\
\hline Alloyohimbine & & $\begin{array}{l}3 \mathrm{CL}^{\text {pro }} \\
\text { inhibitor }\end{array}$ & $\begin{array}{l}\text { Molecular } \\
\text { docking }\end{array}$ & {$[61]$} \\
\hline Amaranthin & & $\begin{array}{l}3 \mathrm{CL}^{\text {pro }} \\
\text { inhibitor }\end{array}$ & $\begin{array}{l}\text { Molecular } \\
\text { docking }\end{array}$ & {$[85]$} \\
\hline Anisotine & & $\begin{array}{c}\text { Mpro } \\
\text { inhibitor }\end{array}$ & $\begin{array}{l}\text { Molecular } \\
\text { docking }\end{array}$ & [59] \\
\hline
\end{tabular}


TABle 2: Continued.

\begin{tabular}{|c|c|c|c|c|}
\hline Alkaloid & Chemical structure & $\begin{array}{l}\text { Mechanisms } \\
\text { of action }\end{array}$ & $\begin{array}{l}\text { Type of } \\
\text { study }\end{array}$ & References \\
\hline Asparagamine A & & $\begin{array}{l}3 \mathrm{CL}^{\text {pro }} \\
\text { inhibitor }\end{array}$ & $\begin{array}{c}\text { Molecular } \\
\text { docking }\end{array}$ & {$[61]$} \\
\hline Berberine & & $\begin{array}{c}3 \mathrm{CL}^{\text {pro }} \\
\text { inhibitory, } \\
\text { blocking } \\
\text { ACE2 and } \\
\text { Nsp15 }\end{array}$ & $\begin{array}{c}\text { Molecular } \\
\text { docking }\end{array}$ & {$[10,39,74]$} \\
\hline Cadambine & & $\begin{array}{c}3 \mathrm{CL}^{\text {pro }} \\
\text { inhibitory }\end{array}$ & $\begin{array}{l}\text { Molecular } \\
\text { docking }\end{array}$ & {$[86]$} \\
\hline Caffeine & & $\begin{array}{l}\text { Blocking } \\
\text { ACE2 }\end{array}$ & $\begin{array}{l}\text { Molecular } \\
\text { docking }\end{array}$ & [83] \\
\hline Chrysopentamine & & $\begin{array}{l}3 \mathrm{CL}^{\text {pro }} \\
\text { inhibitor }\end{array}$ & $\begin{array}{l}\text { Molecular } \\
\text { docking }\end{array}$ & [49] \\
\hline Crambescidin 786 & & $\begin{array}{c}\text { Blocking Nsp } \\
10\end{array}$ & $\begin{array}{l}\text { Molecular } \\
\text { docking }\end{array}$ & {$[82]$} \\
\hline Crambescidin 826 & & $\begin{array}{l}\text { Blocking the } \\
\mathrm{N} \text { proteins }\end{array}$ & $\begin{array}{l}\text { Molecular } \\
\text { docking }\end{array}$ & {$[82]$} \\
\hline
\end{tabular}


TABle 2: Continued.

\begin{tabular}{|c|c|c|c|c|}
\hline Alkaloid & Chemical structure & $\begin{array}{c}\text { Mechanisms } \\
\text { of action }\end{array}$ & $\begin{array}{c}\text { Type of } \\
\text { study }\end{array}$ & References \\
\hline Cryptomisrine & & $\begin{array}{l}\text { Mpro and } \\
\text { RdRp } \\
\text { inhibitor }\end{array}$ & $\begin{array}{l}\text { Molecular } \\
\text { docking }\end{array}$ & {$[50]$} \\
\hline Cryptoquindoline & & $\begin{array}{l}\text { Mpro and } \\
\text { RdRp } \\
\text { inhibitor }\end{array}$ & $\begin{array}{l}\text { Molecular } \\
\text { docking }\end{array}$ & {$[49,50]$} \\
\hline Cryptospirolepine & & $\begin{array}{l}\text { Mpro and } \\
\text { RdRp } \\
\text { inhibitor }\end{array}$ & $\begin{array}{l}\text { Molecular } \\
\text { docking }\end{array}$ & {$[49,50]$} \\
\hline Dihydroergotamine & & $\begin{array}{l}3 \mathrm{CL}^{\text {pro }} \\
\text { inhibitor }\end{array}$ & $\begin{array}{l}\text { Molecular } \\
\text { docking }\end{array}$ & {$[63]$} \\
\hline Epiisopiloturine & & $\begin{array}{c}\text { Mpro } \\
\text { inhibitor }\end{array}$ & $\begin{array}{c}\text { Molecular } \\
\text { docking }\end{array}$ & {$[90]$} \\
\hline Ergometrine & & $\begin{array}{c}\text { Mpro } \\
\text { inhibitor }\end{array}$ & $\begin{array}{c}\text { Molecular } \\
\text { docking }\end{array}$ & {$[65]$} \\
\hline
\end{tabular}


TABle 2: Continued.

\begin{tabular}{|c|c|c|c|c|}
\hline Alkaloid & Chemical structure & $\begin{array}{c}\text { Mechanisms } \\
\text { of action }\end{array}$ & $\begin{array}{l}\text { Type of } \\
\text { study }\end{array}$ & References \\
\hline Ergotamine & & $\begin{array}{l}3 \mathrm{CL}^{\text {pro }} \\
\text { inhibitor }\end{array}$ & $\begin{array}{l}\text { Molecular } \\
\text { docking }\end{array}$ & [63] \\
\hline Fumigatoside E & & $\begin{array}{l}\text { Blocking } \\
\text { ACE2 }\end{array}$ & $\begin{array}{l}\text { Molecular } \\
\text { docking }\end{array}$ & [79] \\
\hline Indican & & $\begin{array}{l}\text { Mpro } \\
\text { inhibitor }\end{array}$ & $\begin{array}{l}\text { Molecular } \\
\text { docking }\end{array}$ & [40] \\
\hline Indigo & & $\begin{array}{c}\text { Mpro } \\
\text { inhibitor }\end{array}$ & $\begin{array}{l}\text { Molecular } \\
\text { docking }\end{array}$ & {$[40]$} \\
\hline Indirubin & & $\begin{array}{l}\text { Mpro } \\
\text { inhibitor }\end{array}$ & $\begin{array}{l}\text { Molecular } \\
\text { docking }\end{array}$ & [40] \\
\hline Nicotine & & $\begin{array}{c}\text { Blocking } \\
\text { ACE2 }\end{array}$ & $\begin{array}{l}\text { Molecular } \\
\text { docking }\end{array}$ & [83] \\
\hline Norquinadoline A & & $\begin{array}{l}\text { Blocking } \\
\text { ACE2 and } \\
\text { PLpro } \\
\text { inhibitor }\end{array}$ & $\begin{array}{l}\text { Molecular } \\
\text { docking }\end{array}$ & {$[80,81]$} \\
\hline
\end{tabular}


TABle 2: Continued.

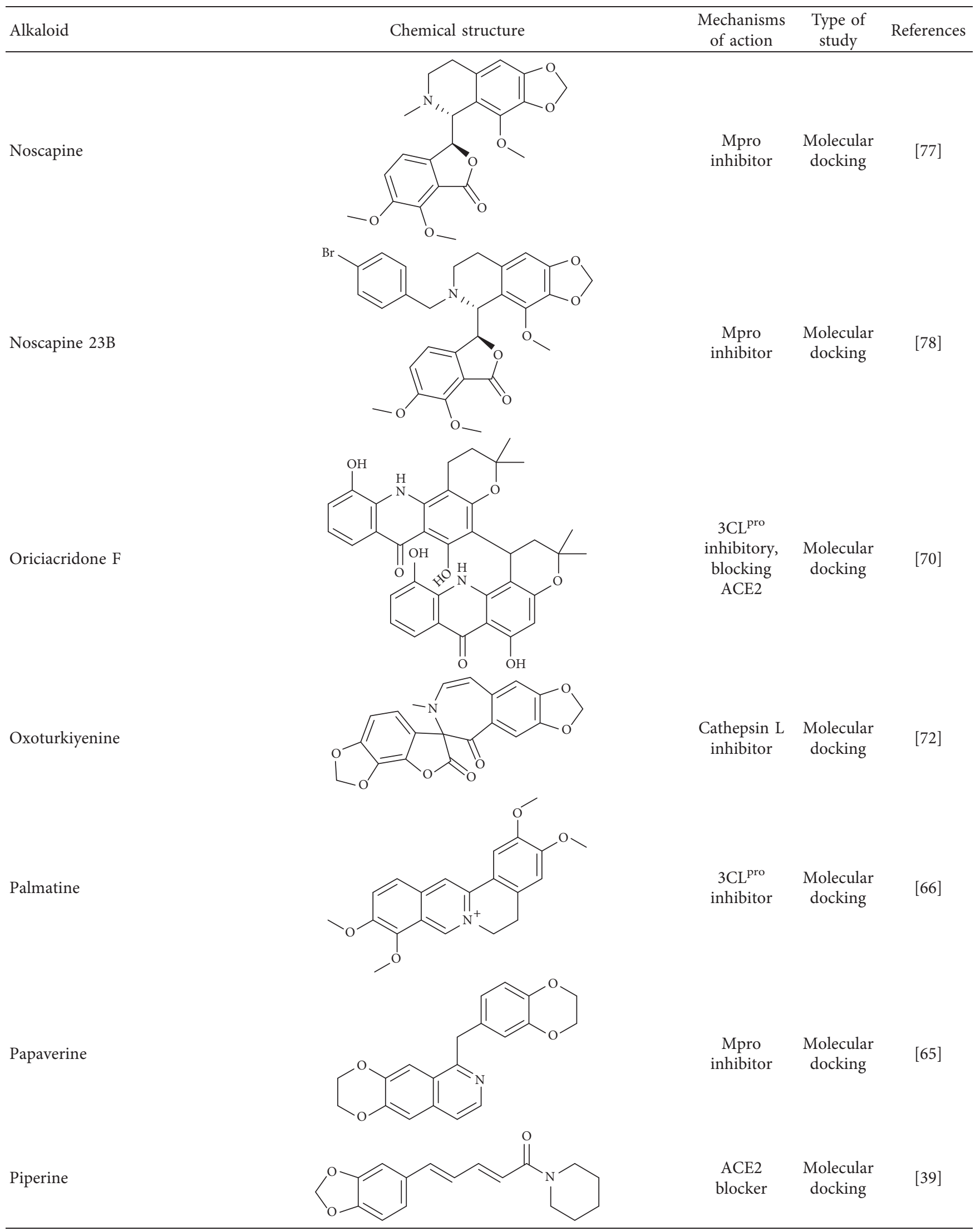


TABLE 2: Continued.

\begin{tabular}{|c|c|c|c|c|}
\hline Alkaloid & Chemical structure & $\begin{array}{l}\text { Mechanisms } \\
\text { of action }\end{array}$ & $\begin{array}{l}\text { Type of } \\
\text { study }\end{array}$ & References \\
\hline Protopine & & $\begin{array}{c}\text { RdRp } \\
\text { inhibitor }\end{array}$ & $\begin{array}{l}\text { Molecular } \\
\text { docking }\end{array}$ & {$[38]$} \\
\hline Pseudojervine & & $\begin{array}{c}\text { ACE2 } \\
\text { blocker }\end{array}$ & $\begin{array}{l}\text { Molecular } \\
\text { docking }\end{array}$ & {$[84]$} \\
\hline Qingdainone & & $\begin{array}{l}\text { Inhibitors of } \\
\text { TMPRSS2 }\end{array}$ & $\begin{array}{l}\text { Molecular } \\
\text { docking }\end{array}$ & {$[72]$} \\
\hline Reserpine & & $\begin{array}{l}\text { Blocking the } \\
\text { Nsp15 }\end{array}$ & $\begin{array}{l}\text { Molecular } \\
\text { docking }\end{array}$ & {$[74]$} \\
\hline Sanguinarine & & $\begin{array}{l}3 \mathrm{CL}^{\text {pro }} \\
\text { inhibitor }\end{array}$ & $\begin{array}{l}\text { Molecular } \\
\text { docking }\end{array}$ & {$[66]$} \\
\hline Solanidine & & $\begin{array}{l}\text { Blocking the } \\
\text { S proteins, } \\
\text { Mpro } \\
\text { inhibitor }\end{array}$ & $\begin{array}{l}\text { Molecular } \\
\text { docking }\end{array}$ & {$[58]$} \\
\hline
\end{tabular}


TABle 2: Continued.

\begin{tabular}{|c|c|c|c|c|}
\hline Alkaloid & Chemical structure & $\begin{array}{c}\text { Mechanisms } \\
\text { of action }\end{array}$ & $\begin{array}{l}\text { Type of } \\
\text { study }\end{array}$ & References \\
\hline Sophaline D & & $\begin{array}{c}\text { Mpro } \\
\text { inhibitor }\end{array}$ & $\begin{array}{c}\text { Molecular } \\
\text { docking }\end{array}$ & {$[45]$} \\
\hline Sophoridine & & $\begin{array}{c}\text { Mpro } \\
\text { inhibitor }\end{array}$ & $\begin{array}{c}\text { Molecular } \\
\text { docking }\end{array}$ & {$[62]$} \\
\hline Speciophylline & & $\begin{array}{l}3 \mathrm{CL}^{\text {pro }} \\
\text { inhibitor }\end{array}$ & $\begin{array}{c}\text { Molecular } \\
\text { docking }\end{array}$ & {$[86]$} \\
\hline Tabersonine & & $\begin{array}{l}3 \mathrm{CL}^{\text {pro }} \\
\text { inhibitor }\end{array}$ & $\begin{array}{l}\text { Molecular } \\
\text { docking }\end{array}$ & {$[66]$} \\
\hline Taspine & & $\begin{array}{l}\text { Blocking } \\
\text { Nsp15 }\end{array}$ & $\begin{array}{l}\text { Molecular } \\
\text { docking }\end{array}$ & {$[74]$} \\
\hline Tetrahydropalmatine & & $\begin{array}{l}3 \mathrm{CL}^{\text {pro }} \\
\text { inhibitor }\end{array}$ & $\begin{array}{l}\text { Molecular } \\
\text { docking }\end{array}$ & {$[10]$} \\
\hline Thalimonine & & $\begin{array}{c}\text { Mpro } \\
\text { inhibitor }\end{array}$ & $\begin{array}{l}\text { Molecular } \\
\text { docking }\end{array}$ & {$[45]$} \\
\hline
\end{tabular}


TABle 2: Continued.

\begin{tabular}{|c|c|c|c|c|}
\hline Alkaloid & Chemical structure & $\begin{array}{c}\text { Mechanisms } \\
\text { of action }\end{array}$ & $\begin{array}{l}\text { Type of } \\
\text { study }\end{array}$ & References \\
\hline Thebaine & & $\begin{array}{c}\text { ACE2 } \\
\text { blocker }\end{array}$ & $\begin{array}{l}\text { Molecular } \\
\text { docking }\end{array}$ & [39] \\
\hline Tryptanthrine & & $\begin{array}{c}\text { Mpro } \\
\text { inhibitor }\end{array}$ & $\begin{array}{l}\text { Molecular } \\
\text { docking }\end{array}$ & {$[40]$} \\
\hline Vincapusine & & $\begin{array}{c}3 \mathrm{CL}^{\text {pro }} \\
\text { inhibitor }\end{array}$ & $\begin{array}{c}\text { Molecular } \\
\text { docking }\end{array}$ & {$[61]$} \\
\hline
\end{tabular}

3CL ${ }^{\text {pro }}$ : 3-chymotrypsin-like protease, ACE2: angiotensin-converting enzyme 2, E proteins: envelope proteins, Mpro: main proteases, NI: not identified, N proteins: nucleocapsid proteins, Nsp15: nonstructural proteins, RdRp: RNA-dependent RNA polymerase, S proteins: spike proteins, TMPRSS2: transmembrane protease serine 2 .

compound in the analysis of ADMET parameters (Ames test) [90].

Quinine, as a Cinchona alkaloid, showed antiviral activities against SARS-CoV-2 at EC90 of $38.8 \mu \mathrm{M}$. Also, quinine had slight cytotoxic effects $(\mathrm{CC} 50>100 \mu \mathrm{M})$ on VERO E6 cell lines. In this line, Roza et al. showed that quinine interacted with Mpro $(-6.2 \mathrm{kcal} / \mathrm{mol})$ and $\mathrm{S}$ proteins $(-5.7 \mathrm{kcal} / \mathrm{mol})$. As fever is one of the most common side effects of COVID-19 and quinine has prominent antipyretic effects, this alkaloid could be introduced as a treatment for handling this complication of COVID-19 [91-93].

In addition, several clinical trials are ongoing on alkaloids such as colchicine (NCT04527562, NCT04392141, NCT04375202, NCT04355143, and NCT04360980), berberine (NCT04479202), and tetrandrine (NCT04308317). Therefore, based on the abovementioned studies, which showed their high efficacy in the treatment of COVID-19 disease, alkaloids could be introduced as hopeful anti-SARSCoV-2 agents. The types of alkaloids, chemical structure, and anti-SARS-CoV-2 mechanisms obtained from in vitro and in silico studies are summarized in Tables 1 and 2, respectively.

\section{Conclusions}

The inherent complexity of SARS-CoV-2 makes it difficult for patients with COVID-19 to find effective treatments. The present study shows that alkaloids, as one of the most widespread natural compounds, hold out the hope for an effective treatment against COVID-19, due to their simultaneous effects on several therapeutic targets with prominent antiviral effects.
Hence, marine/plant-derived alkaloids such as berberine, tetrandrine, cepharanthine, lycorine, ergotamine, crambescidin 786, palmatine, noscapine, and quinine with prominent antiSARS-CoV-2 effects along with antipyretic, anti-inflammatory, antitussive and lung injury, immunomodulatory, and protective effects against neurotoxicity, cardiotoxicity, nephrotoxicity, and hepatotoxicity could be promising candidates for COVID19 treatment $[46,48,52,64,68,76,77,79,82,93]$. Therefore, according to the contents mentioned, extensive and comprehensive clinical studies on these compounds seem to be useful and necessary. Besides, the present study covers a much larger number of alkaloids with anti-SARS-CoV-2 effects and discusses the molecular mechanisms of these compounds in more detail $[94,95]$.

\section{Data Availability}

No data were used to support this study.

\section{Conflicts of Interest}

The authors declare that there are no conflicts of interest regarding the publication of this paper.

\section{References}

[1] A. Sharma, S. Tiwari, M. K. Deb, and J. L. Marty, "Severe acute respiratory syndrome coronavirus-2 (SARS-CoV-2): a global pandemic and treatment strategies," International Journal of Antimicrobial Agents, vol. 56, no. 2, Article ID 106054, 2020. 
[2] A. Ianevski, R. Yao, M. H. Fenstad et al., "Potential antiviral options against SARS-CoV-2 infection," Viruses, vol. 12, no. 6, p. 642, 2020.

[3] S. Fakhri, Z. Nouri, S. Z. Moradi, and M. H. Farzaei, "Astaxanthin, COVID-19 and immune response: focus on oxidative stress, apoptosis and autophagy," Phytotherapy Research: PTR, vol. 34, no. 11, pp. 2790-2792, 2020.

[4] P. Mohammadi Pour, S. Fakhri, S. Asgary, M. H. Farzaei, and J. Echeverría, "The signaling pathways, and therapeutic targets of antiviral agents: focusing on the antiviral approaches and clinical perspectives of anthocyanins in the management of viral diseases," Frontiers in Pharmacology, vol. 10, no. 1207, 2019.

[5] J. S. Mani, J. B. Johnson, J. C. Steel et al., "Natural productderived phytochemicals as potential agents against coronaviruses: a review," Virus Research, vol. 284, Article ID 197989, 2020.

[6] G. A. Cordell, M. L. Quinn-Beattie, and N. R. Farnsworth, "The potential of alkaloids in drug discovery," Phytotherapy Research: An International Journal Devoted to Pharmacological and Toxicological Evaluation of Natural Product Derivatives, vol. 15, no. 3, pp. 183-205, 2001.

[7] S. Dall'Acqua, "Plant-derived acetylcholinesterase inhibitory alkaloids for the treatment of Alzheimer's disease," Botanics: Targets and Therapy, vol. 3, pp. 19-28, 2012.

[8] T. P. T. Cushnie, B. Cushnie, and A. J. Lamb, "Alkaloids: an overview of their antibacterial, antibiotic-enhancing and antivirulence activities," International Journal of Antimicrobial Agents, vol. 44, no. 5, pp. 377-386, 2014.

[9] B. Özçelik, M. Kartal, and I. Orhan, "Cytotoxicity, antiviral and antimicrobial activities of alkaloids, flavonoids, and phenolic acids," Pharmaceutical Biology, vol. 49, no. 4, pp. 396-402, 2014.

[10] P. Chowdhury, "In silico investigation of phytoconstituents from Indian medicinal herb 'Tinospora cordifolia (giloy)'against SARS-CoV-2 (COVID-19) by molecular dynamics approach," Journal of Biomolecular Structure and Dynamics, pp. 1-18, 2020.

[11] K. T. Choy, A. Y. Wong, P. Kaewpreedee et al., "Remdesivir, lopinavir, emetine, and homoharringtonine inhibit SARSCoV-2 replication in vitro," Antiviral Research, vol. 178, Article ID 104786, 2020.

[12] P. F. Rosales, G. S. Bordin, A. E. Gower, and S. Moura, "Indole alkaloids: 2012 until now, highlighting the new chemical structures and biological activities," Fitoterapia, vol. 143, Article ID 104558, 2012.

[13] J. Kurek, "Introductory chapter: alkaloids-their importance in nature and for human life," in Alkaloids-Their Importance in Nature and Human LifeIntechOpen, London, UK, 2019.

[14] N. Babbar, "An introduction to alkaloids and their applications in pharmaceutical chemistry," The Pharma Innovation Journal, vol. 4, no. 10, pp. 74-75, 2015.

[15] L. Yang and J. Stöckigt, "Trends for diverse production strategies of plant medicinal alkaloids," Natural Product Reports, vol. 27, no. 10, pp. 1469-1479, 2010.

[16] G. Hussain, A. Rasul, H. Anwar et al., "Role of plant derived alkaloids and their mechanism in neurodegenerative disorders," International Journal of Biological Sciences, vol. 14, no. 3, pp. 341-357, 2018.

[17] P. Dey, A. Kundu, H. J. Chakraborty et al., "Therapeutic value of steroidal alkaloids in cancer: current trends and future perspectives," International Journal of Cancer, vol. 145, no. 7, pp. 1731-1744, 2019.
[18] X. Feng, A. Sureda, S. Jafari et al., "Berberine in cardiovascular and metabolic diseases: from mechanisms to therapeutics," Theranostics, vol. 9, no. 7, pp. 1923-1951, 2019.

[19] N. Kishore, B. B. Mishra, V. Tripathi, and V. K. Tiwari, "Alkaloids as potential anti-tubercular agents," Fitoterapia, vol. 80, no. 3, pp. 149-163, 2009.

[20] H. L. Li, T. Han, R. H. Liu, C. Zhang, H. S. Chen, and W. D. Zhang, "Alkaloids from Corydalis saxicola and their anti-hepatitis B virus activity," Chemistry \& Biodiversity, vol. 5, no. 5, pp. 777-783, 2008.

[21] A. O’Rourke, S. Kremb, T. M. Bader et al., "Alkaloids from the sponge Stylissa carteri present prospective scaffolds for the inhibition of human immunodeficiency virus 1 (HIV-1)," Marine Drugs, vol. 14, no. 2, p. 28, 2016.

[22] J. He, W. B. Qi, L. Wang et al., "Amaryllidaceae alkaloids inhibit nuclear-to-cytoplasmic export of ribonucleoprotein (RNP) complex of highly pathogenic avian influenza virus H5N1," Influenza and Other Respiratory Viruses, vol. 7, no. 6, pp. 922-931, 2020.

[23] N. Nakamura, M. Hattori, M. Kurokawa, K. Shiraki, N. Kashiwaba, and M. Ono, "Anti-herpes simplex virus activity of alkaloids isolated from Stephania cepharantha," Biological and Pharmaceutical Bulletin, vol. 22, no. 3, pp. 268-274, 1999.

[24] V. A. Fedorova, R. A. Kadyrova, A. V. Slita et al., "Antiviral activity of amides and carboxamides of quinolizidine alkaloid (-)-cytisine against human influenza virus $A(\mathrm{H} 1 \mathrm{~N} 1)$ and parainfluenza virus type 3," Natural Product Research, pp. 1-9, 2019.

[25] P. Houghton, T. Woldemariam, A. Khan, A. Burke, and N. Mahmood, "Antiviral activity of natural and semi-synthetic chromone alkaloids," Antiviral Research, vol. 25, no. 34, pp. 235-244, 1994.

[26] J.-H. Yang, X.-Y. Wang, Y.-P. Zhou et al., "Carbazole alkaloids from Clausena anisum-olens: isolation, characterization, and anti-HIV evaluation," Molecules, vol. 25, no. 1, p. 99, 2019.

[27] M.-M. Cao, Y. Zhang, X.-H. Li et al., "Cyclohexane-fused octahydroquinolizine alkaloids from Myrioneuron faberi with activity against hepatitis C virus," The Journal of Organic Chemistry, vol. 79, no. 17, pp. 7945-7950, 2014.

[28] J. Renard-Nozaki, T. Kim, Y. Imakura, M. Kihara, and S. Kobayashi, "Effect of alkaloids isolated from Amaryllidaceae on herpes simplex virus," Research in Virology, vol. 140, pp. 115-128, 1989.

[29] W.-F. Chiou, H.-C. Ko, and B.-L. Wei, "Evodia rutaecarpa and three major alkaloids abrogate influenza A virus (H1N1)induced chemokines production and cell migration," Evidence-Based Complementary and Alternative Medicine, vol. 2011, Article ID 750513, 10 pages, 2011.

[30] Z. Ren, C.-h. Zhang, L.-j. Wang et al., "In vitro anti-viral activity of the total alkaloids from Tripterygium hypoglaucum against herpes simplex virus type 1," Virologica Sinica, vol. 25, no. 2, pp. 107-114, 2010.

[31] M.-T. Moradi, A. Karimi, M. Rafieian-Kopaei, and F. Fotouhi, "In vitro antiviral effects of Peganum harmala seed extract and its total alkaloids against Influenza virus," Microbial Pathogenesis, vol. 110, pp. 42-49, 2017.

[32] Y. Wang and S. Zhang, "Berberine suppresses growth and metastasis of endometrial cancer cells via miR-101/COX-2," Biomedicine \& Pharmacotherapy, vol. 103, pp. 1287-1293, 2018.

[33] D.-D. Sun, W.-w. Dong, X. Li, and H.-Q. Zhang, "Indole alkaloids from the roots of Isatis ingigotica and their antiherpes simplex virus type 2 (HSV-2) activity in vitro," 
Chemistry of Natural Compounds, vol. 46, no. 5, pp. 763-766, 2010.

[34] S.-y. Li, C. Chen, H.-q. Zhang et al., "Identification of natural compounds with antiviral activities against SARS-associated coronavirus," Antiviral Research, vol. 67, no. 1, pp. 18-23, 2020.

[35] L. Shen, J. Niu, C. Wang et al., "High-throughput screening and identification of potent broad-spectrum inhibitors of coronaviruses," Journal of Virology, vol. 9312 pages, 2019.

[36] H.-X. Zhou, R.-F. Li, Y.-F. Wang et al., "Total alkaloids from Alstonia scholaris inhibit influenza a virus replication and lung immunopathology by regulating the innate immune response," Phytomedicine, vol. 77, Article ID 153272, 2020.

[37] M. Wink, "Potential of DNA intercalating alkaloids and other plant secondary metabolites against SARS-CoV-2 causing COVID-19," Diversity, vol. 12, no. 5, p. 175, 2020.

[38] K. B. Pandeya, A. Ganeshpurkar, and M. K. Mishra, "Natural RNA dependent RNA polymerase inhibitors: molecular docking studies of some biologically active alkaloids of Argemone mexicana," Medical Hypotheses, vol. 144, Article ID 109905, 2020.

[39] V. K. Maurya, S. Kumar, A. K. Prasad, M. L. Bhatt, and S. K. Saxena, "Structure-based drug designing for potential antiviral activity of selected natural products from Ayurveda against SARS-CoV-2 spike glycoprotein and its cellular receptor," Virus Disease, vol. 31, pp. 179-193, 2020.

[40] R. R. Narkhede, A. V. Pise, R. S. Cheke, and S. D. Shinde, "Recognition of natural products as potential inhibitors of COVID-19 main protease (Mpro): in-silico evidences," Natural Products and Bioprospecting, vol. 10, no. 5, pp. 297306, 2020.

[41] Y.-C. Tsai, C.-L. Lee, H.-R. Yen et al., "Antiviral action of tryptanthrin isolated from Strobilanthes cusia leaf against human coronavirus NL63," Biomolecules, vol. 10, no. 3, p. 366, 2020.

[42] S.-J. Chang, Y.-C. Chang, K.-Z. Lu, Y.-Y. Tsou, and C.-W. Lin, "Antiviral activity of Isatis indigotica extract and its derived indirubin against Japanese encephalitis virus," Evidence-Based Complementary and Alternative Medicine, vol. 2012, Article ID 925830, , 2012.

[43] H.-H. Kwok, P.-Y. Poon, S.-P. Fok et al., "Anti-inflammatory effects of indirubin derivatives on influenza A virus-infected human pulmonary microvascular endothelial cells," Scientific Reports, vol. 6, no. 1, p. 18941, 2016.

[44] Y.-K. Lin, Y.-L. Leu, T.-H. Huang et al., "Anti-inflammatory effects of the extract of indigo naturalis in human neutrophils," Journal of Ethnopharmacology, vol. 125, no. 1, pp. 51-58, 2009.

[45] S. Garg and A. Roy, "In silico analysis of selected alkaloids against main protease (Mpro) of SARS-CoV-2," ChemicoBiological Interactions, vol. 332, Article ID 109309, 2020.

[46] D. E. Kim, J. S. Min, M. S. Jang et al., "Natural bis-benzylisoquinoline alkaloids-tetrandrine, fangchinoline, and cepharanthine, inhibit human coronavirus OC43 infection of MRC-5 human lung cells," Biomolecules, vol. 9, no. 11, p. 696, 2019.

[47] Z. Ruan, C. Liu, Y. Guo et al., "SARS-CoV-2 and SARS-CoV: virtual Screening of Potential inhibitors targeting RNA-dependent RNA polymerase activity (NSP12)," Journal of Medical Virology, vol. 93, no. 1, pp. 389-400, 2021.

[48] M. B. Majnooni, S. Fakhri, Y. Shokoohinia et al., "Phytochemicals: potential therapeutic interventions against coronavirus-associated lung injury," Frontiers in Pharmacology, vol. 11, p. 1744, 2020.
[49] G. A. Gyebi, O. B. Ogunro, A. P. Adegunloye, O. M. Ogunyemi, and S. O. Afolabi, "Potential inhibitors of coronavirus 3-chymotrypsin-like protease (3CLpro): an in silico screening of alkaloids and terpenoids from African medicinal plants," Journal of Biomolecular Structure and Dynamics, pp. 1-19, 2020.

[50] L. S. Borquaye, E. N. Gasu, G. B. Ampomah et al., "Alkaloids from Cryptolepis sanguinolenta as potential inhibitors of SARS-CoV-2 viral proteins: an in silico study," BioMed Research International, vol. 2020, Article ID 5324560, 14 pages, 2020.

[51] Y.-N. Zhang, Q.-Y. Zhang, X.-D. Li et al., "Gemcitabine, lycorine and oxysophoridine inhibit novel coronavirus (SARS-CoV-2) in cell culture," Emerging Microbes \& Infections, vol. 9, no. 1, pp. 1170-1173, 2020.

[52] S. Fakhri, S. Piri, M. B. Majnooni, M. H. Farzaei, and J. Echeverría, "Targeting neurological manifestations of coronaviruses by candidate phytochemicals: a mechanistic approach," Frontiers in Pharmacology, vol. 11, 2021.

[53] X. Li, H.-Y. Yu, Z.-Y. Wang, H.-F. Pi, P. Zhang, and H.-L. Ruan, "Neuroprotective compounds from the bulbs of Lycoris radiata," Fitoterapia, vol. 88, pp. 82-90, 2013.

[54] M. D. Bleasel and G. M. Peterson, "Emetine, ipecac, ipecac alkaloids and analogues as potential antiviral agents for coronaviruses," Pharmaceuticals, vol. 13, no. 3, p. 51, 2020.

[55] S. T. S. Hassan, "Shedding light on the effect of natural antiherpesvirus alkaloids on SARS-CoV-2: a treatment option for COVID-19," Viruses, vol. 12, no. 4, p. 476, 2020.

[56] R. Kumar, M. Afsar, N. Khandelwal et al., "Emetine suppresses SARS-CoV-2 replication by inhibiting interaction of viral mRNA with eIF4E," Antiviral Research, vol. 189, Article ID 105056, 2020.

[57] B. C. Fielding, C. da Silva Maia Bezerra Filho, N. S. Ismail, and D. P. d. Sousa, "Alkaloids: therapeutic potential against human coronaviruses," Molecules, vol. 25, no. 23, p. 5496, 2020.

[58] A. Ubani, F. Agwom, O. R. Morenikeji et al., "Molecular docking analysis of some phytochemicals on two SARS-CoV2 targets," bioRxiv, 2020.

[59] R. Ghosh, A. Chakraborty, A. Biswas, and S. Chowdhuri, "Identification of alkaloids from Justicia adhatoda as potent SARS CoV-2 main protease inhibitors: an in silico perspective," Journal of Molecular Structure, vol. 1229, Article ID 129489, 2021.

[60] P. Kar, V. Kumar, B. Vellingiri et al., "Anisotine and amarogentin as promising inhibitory candidates against SARSCoV-2 proteins: a computational investigation," Journal of Biomolecular Structure and Dynamics, pp. 1-11, 2020.

[61] A. B. Gurung, M. A. Ali, J. Lee, M. A. Farah, and K. M. AlAnazi, "Structure-based virtual screening of phytochemicals and repurposing of FDA approved antiviral drugs unravels lead molecules as potential inhibitors of coronavirus 3C-like protease enzyme," Journal of King Saud University-Science, vol. 32, no. 6, pp. 2845-2853, 2020.

[62] A. B. Gurung, M. A. Ali, J. Lee, M. A. Farah, and K. M. AlAnazi, "Unravelling lead antiviral phytochemicals for the inhibition of SARS-CoV-2 Mpro enzyme through in silico approach," Life Sciences, vol. 255, Article ID 117831, 2020.

[63] S. Gul, O. Ozcan, S. Asar, A. Okyar, I. Barıs, and I. H. Kavakli, "In silico identification of widely used and well-tolerated drugs as potential SARS-CoV-2 3C-like protease and viral RNA-dependent RNA polymerase inhibitors for direct use in clinical trials," Journal of Biomolecular Structure and Dynamics, pp. 1-20, 2020. 
[64] S. D. Silberstein, "The pharmacology of ergotamine and dihydroergotamine," Headache, vol. 37, pp. S15-S25, 1997.

[65] E. M. Mostafa, M. Gamal, M. M. Ghoneim et al., "Repurposing of FDA approved alkaloids as COVID 19 inhibitors; in silico studies," Pharmacognosy Journal, vol. 13, no. 1, 2021.

[66] T. Joshi, T. Joshi, H. Pundir, P. Sharma, S. Mathpal, and S. Chandra, "Predictive modeling by deep learning, virtual screening and molecular dynamics study of natural compounds against SARS-CoV-2 main protease," Journal of Biomolecular Structure and Dynamics, pp. 1-19, 2020.

[67] W. Li, H. Li, Q. Mu et al., "Protective effect of sanguinarine on LPS-induced endotoxic shock in mice and its effect on LPSinduced COX-2 expression and COX-2 associated PGE2 release from peritoneal macrophages," International Immunopharmacology, vol. 22, no. 2, pp. 311-317, 2014.

[68] B. Yan, D. Wang, S. Dong et al., "Palmatine inhibits TRIFdependent NF- $\kappa$ B pathway against inflammation induced by LPS in goat endometrial epithelial cells," International Immunopharmacology, vol. 45, pp. 194-200, 2017.

[69] D. Zhang, X. Li, Y. Hu et al., "Tabersonine attenuates lipopolysaccharide-induced acute lung injury via suppressing TRAF6 ubiquitination," Biochemical Pharmacology, vol. 154, pp. 183-192, 2018.

[70] R. S. Joshi, S. S. Jagdale, S. B. Bansode et al., "Discovery of potential multi-target-directed ligands by targeting hostspecific SARS-CoV-2 structurally conserved main protease," Journal of Biomolecular Structure and Dynamics, pp. 1-16, 2020.

[71] C.-W. Yang, Y.-Z. Lee, I.-J. Kang et al., "Identification of phenanthroindolizines and phenanthroquinolizidines as novel potent anti-coronaviral agents for porcine enteropathogenic coronavirus transmissible gastroenteritis virus and human severe acute respiratory syndrome coronavirus," Antiviral Research, vol. 88, no. 2, pp. 160-168, 2010.

[72] R. Vivek-Ananth, A. Rana, N. Rajan, H. S. Biswal, and A. Samal, "In silico identification of potential natural product inhibitors of human proteases key to SARS-CoV-2 infection," Molecules, vol. 25, no. 17, p. 3822, 2020.

[73] Z. Gao, B. Xia, X. Shen et al., "SARS-CoV-2 envelope protein causes acute respiratory distress syndrome (ARDS)-like pathological damage and constitutes an antiviral target," bioRxiv, 2020.

[74] S. Kumar, P. Kashyap, S. Chowdhury, S. Kumar, A. Panwar, and A. Kumar, "Identification of phytochemicals as potential therapeutic agents that binds to Nsp15 protein target of coronavirus (SARS-CoV-2) that are capable of inhibiting virus replication," Phytomedicine, vol. 85, Article ID 153317, 2020.

[75] C.-L. Kuo, C.-W. Chi, and T.-Y. Liu, "The anti-inflammatory potential of berberine in vitro and in vivo," Cancer Letters, vol. 203, no. 2, pp. 127-137, 2004.

[76] M. A. Neag, A. Mocan, J. Echeverría et al., "Berberine: botanical occurrence, traditional uses, extraction methods, and relevance in cardiovascular, metabolic, hepatic, and renal disorders," Frontiers in Pharmacology, vol. 9, p. 557, 2018.

[77] N. Kumar, D. Sood, P. J. van der Spek, H. S. Sharma, and R. Chandra, "Molecular binding mechanism and pharmacology comparative analysis of noscapine for repurposing against SARS-CoV-2 protease," Journal of Proteome Research, vol. 19, no. 11, pp. 4678-4689, 2020.

[78] D. Kumar, K. Kumari, A. Jayaraj et al., "Understanding the binding affinity of noscapines with protease of SARS-CoV-2 for COVID-19 using MD simulations at different temperatures," Journal of Biomolecular Structure and Dynamics, vol. 39, no. 7, pp. 2659-2672, 2020.

[79] F. S. Youssef, E. Alshammari, and M. L. Ashour, "Bioactive alkaloids from genus Aspergillus: mechanistic interpretation of their antimicrobial and potential SARS-CoV-2 inhibitory activity using molecular modelling," International Journal of Molecular Sciences, vol. 22, no. 4, p. 1866, 2021.

[80] E. M. Ismail, S. W. Shantier, M. S. Mohammed, H. H. Musa, W. Osman, and R. A. Mothana, "Quinoline and quinazoline alkaloids against COVID-19: an in silico multitarget approach," Journal of Chemistry, vol. 2021, Article ID 3613268, 11 pages, 2021.

[81] M. T. J. Quimque, K. I. R. Notarte, R. A. T. Fernandez et al., "Virtual screening-driven drug discovery of SARS-CoV2 enzyme inhibitors targeting viral attachment, replication, post-translational modification and host immunity evasion infection mechanisms," Journal of Biomolecular Structure and Dynamics, pp. 1-18, 2020.

[82] A. El-Demerdash, A. M. Metwaly, A. Hassan et al., "Comprehensive virtual screening of the antiviral potentialities of marine polycyclic guanidine alkaloids against SARS-CoV-2 (COVID-19)," Biomolecules, vol. 11, no. 3, p. 460, 2021.

[83] S. Mohammadi, M. Heidarizadeh, M. Entesari et al., "In silico investigation on the inhibiting role of nicotine/caffeine by blocking the S protein of SARS-CoV-2 versus ACE2 receptor," Microorganisms, vol. 8, no. 10, p. 1600, 2020.

[84] J. Cheng, Y. Tang, B. Bao, and P. Zhang, "Exploring the active compounds of traditional mongolian medicine Agsirga in intervention of novel coronavirus (2019-nCoV) based on HPLC-Q-exactive-MS/MS and molecular docking method," Journal of Functional Foods, vol. 71, Article ID 104016, 2020.

[85] M. T. ul Qamar, S. M. Alqahtani, M. A. Alamri, and L. Chen, "Structural basis of SARS-CoV-2 3CLpro and anti-COVID-19 drug discovery from medicinal plants," Journal of Pharmaceutical Analysis, vol. 10, no. 4, pp. 313-319, 2020.

[86] A. F. Yepes-Pérez, O. Herrera-Calderon, J.-E. SánchezAparicio, L. Tiessler-Sala, J.-D. Maréchal, and W. Cardona-G, "Investigating potential inhibitory effect of uncaria tomentosa (Cat's Claw) against the Main Protease 3CLpro of SARS-CoV2 by Molecular Modeling," Evidence-Based Complementary and Alternative Medicine, vol. 2020, Article ID 4932572, 14 pages, 2020.

[87] M. Alfaro, I. Alfaro, and C. Angel, "Identification of potential inhibitors of SARS-CoV-2 papain-like protease from tropane alkaloids from Schizanthus porrigens: A molecular docking study," Chemical Physics Letters, vol. 761, Article ID 138068, 2020.

[88] L. Huang, H. Li, T. T.-T. Yuen et al., "Berbamine inhibits the infection of SARS-CoV-2 and flaviviruses by compromising TPRMLs-mediated endolysosomal trafficking of viral receptors," Research Square, 2020.

[89] C.-L. He, L.-Y. Huang, K. Wang et al., "Identification of bisbenzylisoquinoline alkaloids as SARS-CoV-2 entry inhibitors from a library of natural products," Signal Transduction and Targeted Therapy, vol. 6, no. 1, pp. 1-3, 2021.

[90] É. R. de Sá, A. N. Costa, R. K. Costa, J. L. Souza, R. M. Ramos, and F. . d.C. Lima, "In silico study of the interactions of Pilocarpus microphyllus imidazolic alkaloids with the main protease (Mpro) of SARS-CoV-2," Molecular Simulation, vol. 47, no. 1, pp. 1-14, 2021.

[91] M. Gendrot, J. Andreani, M. Boxberger et al., "Antimalarial drugs inhibit the replication of SARS-CoV-2: An in vitro evaluation," Travel Medicine and Infectious Disease, vol. 37, Article ID 101873, 2020. 
[92] F. Santos and V. Rao, "A study of the anti-pyretic effect of quinine, an alkaloid effective against cerebral malaria, on fever induced by bacterial endotoxin and yeast in rats," Journal of Pharmacy and Pharmacology, vol. 50, no. 2, pp. 225-229, 1998.

[93] D. Roza, R. Selly, R. Munsirwan, and G. Fadhilah, "Molecular docking of quinine derivative as inhibitor in Sars-Cov-2," Journal of Physics: Conference Series, vol. 1819, no. 1, Article ID 012053, 2021.

[94] D. Aydin, M. Gürü, and S. Gürü, "Effect of alkaloids on SARSCoV-2," NATURENGS MTU Journal of Engineering and Natural Sciences, pp. 10-18, 2020.

[95] H. Ş. Gülaçtı Topçu, A. T. Gülbahar Özge, and M. A. Vecdi, "Natural alkaloids as potential anti-coronaviruse compounds," Bezmialem Science, vol. 8, pp. 131-139, 2020. 